\title{
Proposição de roteiros ecoturísticos e de turismo de aventura como alternativa de desenvolvimento no município de Acari (RN)
}

\section{A proposal for ecotourism and adventure tourism circuits as an alternative to development in the municipality of Acari (RN, Brazil)}

Wilker Ricardo de Mendonça Nóbrega, Ítalo Victor de Souza Dantas

\section{RESUMO}

O objetivo principal desse trabalho é propor roteiros ecoturísticos e de turismo de aventura na região do Açude Gargalheira, município de Acari/RN, buscando viabilizar o desenvolvimento socioeconômico da localidade, balizado na perspectiva do uso racional dos recursos naturais. Para tanto, foram demandados esforços na realização do inventário da oferta turística local. Também foi realizado um levantamento da infraestrutura de apoio e turística do município. Necessitou-se ainda de uma hierarquização dos atrativos turísticos inventariados, estabelecendo a potencialidade e representatividade que cada atrativo possui. A metodologia utilizada para realização desse processo foi a proposta pelo Ministério do Turismo - MTUR (2011) adaptada do Centro Interamericano de Capacitação Turística (CICATUR). Além disso, também foi analisado o perfil dos turistas e visitantes em Acari com intuito de identificar as características da demanda que visita o município. Por último, foram propostos dois roteiros ecoturísticos, compostos pela visitação de cinco diferentes localidades, todos nas serras que circundam o Açude Gargalheira. Neles são contempladas várias atividades, desde interpretação do ambiente natural, definição de trilhas, prática de rapel, escalada, e visitação de sítios arqueológicos. Os resultados apontaram que, a criação de roteiros ecoturísticos e de turismo de aventura no município de Acari ( $R N$ )são alternativas viáveis na busca pela diversificação da oferta turística e do desenvolvimento socioeconômico local.

PALAVRAS-CHAVE: Roteiros Ecoturísticos; Turismo de Aventura; Desenvolvimento Local; Acari (RN). 


\section{ABSTRACT}

The objective of this paper is to propose ecotourism circuits and adventure tourism in the Açude Gargalheira (Gargalheira dam) region, located in the municipality of Acari, Rio Grande do Norte state (RN), Brazil, in an effort to promote viable socioeconomic development in the region based on the perspective of rational use of natural resources. To that end our efforts went into building an inventory of local tourist attractions. Additionally we surveyed supporting infrastructure and tourism infrastructure in the municipality. Next, we developed a hierarchy of the inventoried tourist attractions so as to establish the potential and significance of each attraction. Our methodology followed that of the Ministry of Tourism - MTUR (2011) which was adapted from the Centro Interamericano de Capacitação Turística (Inter-American Center for Tourism Capacity Building - CICATUR). Furthermore, we analyzed Acari visitor and tourist profiles with the intention of identifying consumer characteristics. Finally, we proposed two tourism circuits which include visitation to five different sites, all of which are located in the valleys that surround the Gargalheira Açude. Within these tourist circuits, various activities are contemplated, including: interpreting the natural environment, walking trails, rappel and rock climbing, and visits to archeological sites. Our results indicate that ecotourism and adventure circuits in the municipality of Acari, (RN, Brazil) are a viable alternative to both the diversification of tourism in the region and local socioeconomic development.

KEYWORDS: Ecotourism Circuits; Adventure Tourism; Local Development; Acari (RN, Brazil).

\section{Introdução}

O fluxo de pessoas interessadas em desfrutar de áreas naturais vem crescendo em todo o mundo. O perfil de pessoas ávidas por uma maior interação com a natureza, com povos tradicionais, em busca da sensação de alívio e descanso que esses locais podem proporcionar. Além disso, o mercado turístico atento às novas exigências e preferências dos consumidores, tem formatado e lançado inúmeros produtos e serviços turísticos com base no uso de recursos naturais, o que contribuiu para o incremento do segmento ecoturístico em todo o mundo. Segundo a Organização Mundial do Turismo (OMT), enquanto o turismo cresce $7,5 \%$ ao ano, o ecoturismo cresce mais de $20 \%$ (OMT, 2011).

No Brasil, com uma política de turismo intencionada a promover 0 setor ecoturístico, o Estado passou a considerar a atividade um elemento essencial para o desenvolvimento socioeconômico do país, então, mais que incrementar o turismo, buscou-se diversificar a oferta turística vigente, bem como descentralizar o planejamento turístico. Para tanto, foram lançados diversos programas e planos. Na região amazônica, por exemplo, foi trabalhado o Programa de Desenvolvimento do Ecoturismo na Amazônia Legal (PROECOTUR); na Região Nordeste, o Programa de Desenvolvimento do Turismo (PRODETUR). No território nacional brasileiro também ocorreram algumas ações que desenharam um constructo da política atual brasileira, isto é, princípios de descentralização e gestão participativa através do Programa Nacional de Municipalização do Turismo 
(PNMT). Mais recentemente acompanhamos um esforço federal em consolidar uma política nacional de turismo tendo como principal preceito o Programa de Regionalização do Turismo (PRT). Este programa busca gerar produtos turísticos competitivos em nível internacional em todas as regiões brasileiras. O PRT prevê ainda diversificar a oferta turística do Brasil de forma a adentrar no interior do território brasileiro. Diante disso, seria importante refletir se a simples criação e oferta de roteiros ecoturísticos seriam capazes de gerar desenvolvimento turístico em pequenos e médios municípios brasileiros. A capacidade gerencial e estrutural dos municípios brasileiros permite a execução de ações integradas que envolvem o poder público, terceiro setor, iniciativa privada e população local para uma diversificação econômica pautada na exploração de atrativos e serviços turísticos de forma que atenda as expectativas de todos os atores envolvidos.

Como forma de responder estas indagações levantadas neste trabalho, o objetivo geral se propôs refletir acerca da criação de roteiros ecoturísticos como possível ferramenta de diversificação e desenvolvimento local no município de Acari, Estado do Rio Grande do Norte. Para tanto, a fim de alcançar tal objetivo, foi necessário atingir os seguintes objetivos específicos: a) Inventariar os atrativos naturais em potencial do local para o desenvolvimento do ecoturismo; b) Hierarquizar os principais atrativos naturais da localidade que comporão os roteiros e; c) Analisar o perfil dos turistas que visitam o município de Acari/RN.

A metodologia foi baseada em uma pesquisa exploratória bibliográfica e digital, além de uma pesquisa de campo na região serrana do Açude Gargalheira e na cidade de Acari caracterizada por um inventário turístico em virtude do levantamento das infraestruturas de apoio e turística utilizando os formulários de inventariação da proposta metodológica do MTUR (2011). O estudo identificou as localidades propícias para exploração do ecoturismo e do turismo de aventura. Após inventariação dos atrativos, foi dado início ao processo de hierarquização de cada um deles, definindo sua representatividade e potencialidade turística. $O$ processo de hierarquização dos atrativos naturais inventariados teve como base a Metodologia de Hierarquização dos Atrativos Turísticos proposta pelo MTUR (2005) adaptada do Centro Interamericano de Capacitação Turística (CICATUR). A aplicação dessa metodologia teve como objetivo avaliar a importância e representatividade dos atrativos para inclusão nos roteiros ecoturísticos.

O estudo possui natureza aplicada, pois segundo Gil (1999, p.42) “a pesquisa tem como objetivo gerar conhecimentos para aplicações práticas dirigidas à solução de problemas específicos". Ainda, o problema tem uma abordagem quantitativa e dessa maneira buscou-se interpretar as opiniões e dados fornecidos pelos turistas em informações que foram classificadas e analisadas com o intuito de determinar o perfil dos turistas. O levantamento foi o procedimento técnico usado na investigação, pois envolveu 0 questionamento direto das pessoas cujo comportamento se desejou conhecer, e a ferramenta utilizada para coleta desses dados foi a aplicação de formulários. Além disso, foi realizada uma análise do perfil socioeconômico dos turistas em visita a Acari, com intuito de identificar 
variáveis como: anseios, expectativas, satisfação, gastos monetários, motivação da viagem, entre outras.

Por último, para dar uma dimensão espacial do percurso realizado durante as trilhas que compõe os roteiros, através da utilização do Google Earth foi elaborada uma representação cartográfica (croqui), identificando cada serra que comporá o produto turístico.

\section{Ecoturismo e turismo de aventura: uma alternativa ao turismo de massa}

Em resposta à busca por um turismo alternativo e a formatação de produtos turísticos em áreas naturais, o ecoturismo surgiu como a atividade capaz de unir tais aspectos ao paradigma da sustentabilidade, formatando assim uma nova perspectiva de desenvolvimento do turismo capaz de não só suprir os anseios dos visitantes, bem como de respeitar os limites impostos naturalmente pelo meio ambiente. Torna-se, dessa maneira, uma das opções de turismo mais expressivas da atualidade. Diante do esforço de se conceituar a atividade ecoturística por distintos segmentos da sociedade, como o trade turístico, a academia, a mídia, entidades e organizações é que se buscou identificar o conceito mais próximo do que defendemos como ideal, para tanto são destacados alguns deles. Swarbrooke (2000, p.55) afirma que o ecoturismo é:

O desejo de ver ecossistemas em seu estado natural, sua vida selvagem assim como sua população nativa. Contudo, muitas vezes se considera ecoturismo como sendo mais do que isso. Seus defensores afirmam que ele se relaciona também a um desejo de ver ecossistemas preservados e que a população local vive melhor por conta dos efeitos do turismo.

Já nas Diretrizes para uma Política Nacional de Ecoturismo (1994, p.5) prevê que o ecoturismo é:

O segmento da atividade turística que utiliza, de forma sustentável, o patrimônio natural e cultural, incentiva sua conservação e busca a formação de uma consciência ambientalista através da interpretação do ambiente, promovendo o bem-estar das populações envolvidas. ecoturismo é:

Crosby et. al. (1993, apud PIRES, 2002, p.104) afirma que

O segmento turístico em que a paisagem é a principal variável como ponto de confluência dos fatores ambientais e antrópicos. O objetivo é a integração do visitante com o meio natural e humano, e a população local participa dos serviços prestados aos turistas. [...] prioriza a preservação do espaço natural em que é realizado e seu projeto contempla a conservação antes de qualquer outra atividade. 
Mesmo com algumas diferenças conceituais, é possível identificar que três características são comuns as diferentes definições dadas pelos autores, são elas: a garantia de conservação ambiental, a educação ambiental e a geração de benefícios às comunidades receptoras. Desse modo, a atividade deve a partir da utilização de instrumentos como o estudo da capacidade de carga e plano de manejo, gerenciar a utilização controlada dos recursos naturais e culturais da localidade. Além disso, deve garantir que exista a interação entre o ser humano e natureza e que isso possa desencadear uma reflexão a respeito da exploração dos recursos e sua utilização de forma sustentável (PIRES, 2002; NÓBREGA, 2007).

Diversos são os segmentos em que suas atividades podem ser englobadas às do ecoturismo, tendo em vista possuírem características e finalidade em comum, tais como: turismo cultural, rural, científico, educacional e turismo de aventura. A prática de esportes de aventura pode configurar-se como uma boa oportunidade no que diz respeito à agregação de valor ao produto ecoturístico, visto que o turista poderá desfrutar de momentos de lazer sem comprometer o ideal proposto no ecoturismo. Porém, é necessário que haja harmonia entre ambas as atividades, já que a disposição de atividades esportivas pode desvirtuar de alguma maneira o propósito contido no ecoturismo.

A prática do turismo de aventura é um segmento que cresce bastante no Brasil, devido principalmente a grande diversidade natural que o país possui. Há diferentes tipos de relevo, formações rochosas, cachoeiras, rios, florestas, extenso litoral, cânions, entre outros aspectos que propiciam a prática de inúmeras atividades inseridas dentro do segmento, como por exemplo, o rapel, escaladas, motocross, canoagem, kite surf, mergulho, arvorismo, bungee jumping, trilhas, entre outras. O turismo de aventura de acordo com Figueiredo e Campos (2007, p.38) é:

O deslocamento de pessoas de uma região para outra, tendo como motivação principal o desenvolvimento de atividades esportivas de aventura em ambientes naturais, construídos, urbanos ou rurais, como: trilhas, rios, lagoas, praias, céu, montanhas, cavernas, prédios, pontes, torres e outros locais.

Assim, tal segmento compreende os fluxos turísticos decorrentes da prática de atividades vinculadas à aventura com caráter recreativo e não competitivo. A prática de aventura pode ser abordada sob aspectos distintos: como o de responsabilidade individual do turista, quando não há interferência dos prestadores de serviços turísticos no que se refere especificamente à prática da atividade de aventura e sob o aspecto de responsabilidade conjunta ou solidária, que é referente às atividades conduzidas, organizadas ou intermediadas via prestadoras de serviços do turismo que dependem da orientação de profissionais qualificados e de equipamentos e técnicas que propiciem, além da prática adequada, a segurança dos profissionais e dos turistas (MTUR, 2008b). 
O turismo de aventura mostrou-se como uma grande oportunidade para o Brasil despontar no cenário internacional. Abarcado por sua grande diversidade natural, o país possui grande potencial para desenvolver tal atividade. Ainda, se trabalhado aliado ao ecoturismo, prevendo a interação com a comunidade local, o respeito à natureza em virtude de sua relação intrínseca, e a busca pela conservação, podem tornar-se peças fundamentais para o desenvolvimento local / regional.

Porém, para que isso ocorra, é necessário que haja um planejamento turístico adequado capaz de prever as necessidades locais, impactos futuros, integração do trade, participação comunitária e demais fatores de essencial importância para o crescimento econômico e o desenvolvimento sustentável do turismo. Desse modo, o planejamento turístico configura-se como uma ferramenta essencial para concepção do desenvolvimento local a partir da premissa da sustentabilidade.

\section{O processo de planejamento do turismo}

O Brasil por possuir grande diversidade cultural e natural, tem um grande potencial turístico. Porém todo esse potencial ainda não é explorado na sua totalidade ou pelo menos não como deveria, visto que o país exerce na atividade, apenas $1 \%$ do fluxo turístico mundial, o que para um país com dimensões continentais é muito pouco em virtude da singularidade de cada região que, junto a outros aspectos podem atingir diferentes nichos e demandas de mercado e que poderiam contribuir para aumentar essa estatística (FREITAS, 2009).

Isso se deve em parte, à ineficiência do planejamento turístico, ou ainda, da falta dele, o que acaba prejudicando o desenvolvimento econômico e social que a atividade é capaz de proporcionar às localidades receptoras. Portanto o turismo, como qualquer outro setor, apresenta problemas, esses resultantes de fracassos e imperfeições do mercado e das subsequentes respostas do governo e devido aos problemas que o cercam, tais como: de análise, monitorização, coordenação e elaboração de políticas (HALL, 2004; NÓBREGA, 2012).

Porém essa realidade ao longo do tempo está mudando, atualmente, a preocupação com 0 aspecto do planejamento, especialmente 0 da sustentabilidade da atividade turística tem sido tema de amplo debate entre autoridades e especialistas. Isso tem refletido uma nova concepção de desenvolvimento baseada num planejamento estratégico, capaz de prever impactos sociais, econômicos, culturais e ambientais, sejam eles de caráter positivo ou negativo, respeitando, dessa maneira, os limites para o crescimento. Para Hall (2004) e Ruschmann (2001), o planejamento deve ter a capacidade de evitar impactos negativos; envolver todos os interessados; estimular a conservação; ser pluralista, compreendendo as dimensões sociais, econômicas e físicas; considerar o equilíbrio social; ser estratégico e integrador.

Desse modo, pode-se caracterizar o planejamento turístico como sendo o processo que visa, a partir de uma situação dada, orientar o desenvolvimento turístico de um empreendimento, local, região, município, estado ou país, utilizando-se de técnicas como o inventário dos recursos 
turísticos naturais e culturais, apontando seus diferenciais e analisando a atual situação em que se encontra, desse modo, é possível alcançar os objetivos propostos anteriormente ou durante a própria elaboração do planejamento, estabelecendo ainda as políticas e planos de turismo necessários, bem como a viabilidade, controle e gestão de todos os processos (LOHMANN; PANOSSO NETTO, 2008; BENI, 2000).

Assim, o planejamento turístico torna-se essencial para regiões, empreendimentos e localidades que desejam implementar o turismo como atividade econômica, tendo em vista os efeitos negativos que o fenômeno pode gerar em detrimento da má e ineficaz gestão, essa que ocorre na maioria dos lugares pela falta de conhecimento do setor por parte dos profissionais que estão a frente dos órgãos, entidades e empresas responsáveis pelo processo de planejamento e promoção do turismo.

O turismo contemporâneo é um grande consumidor da natureza e sua evolução, nas últimas décadas, ocorreu como consequência da "busca do verde" e da "fuga" dos tumultos dos grandes conglomerados urbanos [...] As consequências do grande afluxo de pessoas nesses ambientes - extremamente sensíveis - fazem com que o planejamento dos espaços, dos equipamentos e das atividades turísticas se apresente como fundamental para evitar os danos sobre os meios visitados e manter a atratividade dos recursos para as gerações futuras (RUSCHMANN, 2001, p.9).

Por outro lado, é necessário estabelecer estratégias, premissas e planos para que a atividade possa ser desempenhada da melhor maneira possível, portanto o planejamento deve ser um aspecto indissociável das localidades que desejam iniciar a exploração do turismo, bem como daquelas que precisam passar por mudanças a fim de melhorar a qualidade de seus produtos e serviços, ou ainda daquelas que perceberam a necessidade do planejamento turístico em virtude dos processos conduzidos de maneira errônea e que já se refletiram em impactos negativos.

No turismo, o processo de planejamento deve passar por diversas fases e etapas, podendo ser elaborado com medidas de curto, médio e longo prazo. O ideal é desenvolvê-lo numa perspectiva de longo prazo, em virtude de suas diretrizes que podem ser alteradas e moldadas de acordo com as necessidades aparentes. Além disso, deve conter objetivos gerais e específicos, assim como, abordagem, ações e metas que incluam a participação direta do setor público e privado, mas principalmente da sociedade. O estudo tem início na busca das informações referentes à localidade alvo do planejamento, o núcleo receptor, através de análises de vários pontos como: oferta e demanda turística, núcleo emissor e comunidade local. Braga (2007) afirma para que isso ocorra, o planejamento turístico deve passar por cinco fases, são elas: Introdução, Inventário, Diagnóstico, Prognóstico e Estruturação das diretrizes de ação. 
Dessa forma, o planejamento turístico se torna imprescindível para que haja realmente o desenvolvimento do turismo na localidade de maneira sustentável, podendo beneficiar e melhorar a qualidade de vida da população local e fortalecer os demais segmentos de mercado existentes na localidade estejam eles ligados diretamente ou não ao turismo. Outro aspecto importante no planejamento da atividade é a hierarquização dos atrativos turísticos. A partir dessa avaliação, pode-se determinar o potencial turístico do atrativo, o que se caracteriza como um elemento fundamental no estabelecimento de estratégias para o local e no fornecimento de subsídios que ajudam a determinar a abrangência de projetos, quantidade e qualidade dos equipamentos, além da infraestrutura a instalar (RUSCHMANN, 2001).

A atratividade de um determinado local é subjetiva, o que para determinado grupo de pessoas é muito interessante, para outro pode ser indiferente. Porém, um atrativo que seja único, sem outros semelhantes, geralmente possui maior valor para os turistas. Em detrimento disso, teve-se como base a Metodologia de Hierarquização dos Atrativos Turísticos proposta pelo MTUR adaptada do Centro Interamericano de Capacitação Turística (CICATUR).

A aplicação dessa metodologia tem como objetivo principal avaliar a importância dos atrativos identificados para inclusão no roteiro turístico. Com este instrumento são estabelecidas prioridades para determinar a escolha e as decisões das entidades públicas e privadas, gestores e empreendedores. Em primeiro lugar, deve-se avaliar o potencial de atratividade do elemento conforme as características e peculiaridades e 0 interesse que pode despertar nos turistas. Posteriormente, são avaliados os aspectos que definem a hierarquia. Esse critério permite classificar cada atrativo de acordo com uma escala preestabelecida. Assim, pode fornecer subsídios para a diferenciação objetiva das características e do nível de importância de cada atrativo.

Essa classificação é importante na composição de roteiros turísticos, pois ajuda a focalizar investimentos e na proposição de infraestruturas envoltas aos atrativos que realmente são capazes de atrair fluxos consideráveis de turistas. Para tanto, uma nova perspectiva de desenvolvimento apontada pelo Governo Federal se dá através da formatação de roteiros turísticos, estes criados a partir do ponto de vista do planejamento turístico regional, em virtude disso, foi lançado o programa Roteiros do Brasil que propõe o desenvolvimento da atividade turística de forma regionalizada, com foco no planejamento coordenado e participativo. Essa perspectiva torna-se uma alternativa viável para o crescimento da atividade, principalmente nas pequenas localidades, além disso, pode contribuir para uma maior organização da oferta turística, bem como na diversificação desta oferta.

\section{A função do roteiro na organização da oferta turística}

Já faz algum tempo que, entidades e órgãos públicos, bem como operadoras e agências de viagens tem explorado os atrativos naturais e culturais em diversas regiões, inclusive em áreas de conservação e proteção ambiental, por meio da elaboração de roteiros turísticos, esses se 
configuram como uma forma de projetar a viagem no intuito de percorrer os espaços em um determinado período de tempo, conhecendo os atrativos e utilizando-se de serviços ofertados ao turista no destino e que são de fundamental importância para que o roteiro tenha o êxito esperado na sua operacionalização.

A roteirização turística pode ser entendida como o processo que propõe aos diversos atores envolvidos com a atividade, orientações para a formatação de roteiros turísticos. Essas orientações auxiliam na integração e organização dos atrativos, equipamentos, serviços turísticos e infraestrutura de apoio ao turismo, o que resulta em uma maior consolidação dos produtos de determinada localidade ou região, e ainda, acaba conferindo maior uso turístico aos atrativos que estão dispersos e que por isso recebem menor fluxo turístico. O roteiro turístico é um itinerário caracterizado por elementos que formam sua identidade, ele é definido e estruturado para fins de planejamento, gestão, promoção e comercialização do produto turístico (MTUR, 2007). De acordo com Bahl (2004, p.31):

\begin{abstract}
Um roteiro turístico resume todo um processo de ordenação de elementos intervenientes na efetivação de uma viagem. Um roteiro pode estabelecer as diretrizes para desencadear a posterior circulação turística, seguindo determinados trajetos, criando fluxos e possibilitando um aproveitamento racional dos atrativos a visitar.
\end{abstract}

Assim, a concepção de roteiros pode proporcionar um melhor ordenamento e disseminação da demanda em todas as localidades da região. Os roteiros aqui propostos possibilitarão uma nova perspectiva para o desenvolvimento do ecoturismo no município de Acari. As características desse tipo de roteiro são peculiares, pois incluem passeios e atividades que podem durar horas ou até mesmo dias e são compostos por tarefas que contemplam a natureza. Esse tipo de roteiro carece ser elaborado a partir de uma perspectiva de uso sustentável dos aspectos naturais, pois os atrativos, bem com os lugares onde são desenvolvidas as atividades, além de praticados os esportes de aventura devem ser conservados para que a exploração dos segmentos possa se suceder por tempo indeterminado, trazendo dessa maneira possíveis inúmeros benefícios para sociedade onde se encontram.

O roteiro turístico também é importante na organização da oferta turística local, tendo em vista que pode proporcionar a identificação e potencializar a atratividade do destino, tornando-o mais rentável e comercialmente viável. Em virtude dessa organização, podem ser gerados mais empregos e postos de trabalho, além de uma maior circulação do dinheiro. Assim, com o estudo das condições para o desenvolvimento do turismo, de modo a aproveitar o potencial dos atrativos turísticos a partir do planejamento da atividade, as chances para que haja o desenvolvimento econômico na região podem ser maiores (MTUR, 2007).

Deve-se entender a roteirização turística como um aspecto fundamental, devido ao papel que pode exercer no desenvolvimento 
socioeconômico de determinada região. Quando implantada da maneira correta pode contribuir para o aumento do fluxo de turistas no destino, assim como aumentar o tempo de permanência e os gastos que realizam durante a viagem. Isso faz com que haja uma melhor distribuição da renda, a partir da criação e do aumento de postos de trabalho, em consequência ao crescimento organizado e planejado do fluxo turístico do destino, o que representa um maior volume de recursos financeiros chegando e circulando na região.

\section{O município de Acari: aspectos históricos, geográficos, econômicos e turísticos}

O município de Acari está localizado na região do Seridó norte riograndense, a $209 \mathrm{~km}$ da capital do estado, mais precisamente na Microrregião do Seridó Oriental, na Mesorregião Central Potiguar e no Polo Seridó, como pode ser observado na Figura 1 (página seguinte). De acordo com o censo realizado pelo Instituto Brasileiro de Geografia e Estatística (IBGE) no ano 2010, a população é formada por 11.035 habitantes, sendo 8.841 residentes na área urbana e 2.194 na zona rural, 5.364 pessoas da população residente são homens enquanto 5.671 são mulheres. Sua área territorial compreende $609 \mathrm{~km}^{2}$ e a densidade demográfica é de 18,13 (hab/ $\left./ \mathrm{km}^{2}\right)$. A economia local é baseada principalmente na agricultura, na pecuária e no setor de serviços (IBGE, 2010).

Acari $(\mathrm{RN})$ é um dos municípios mais antigos do interior do Estado do Rio Grande do Norte. Por ser uma das localidades nas quais começaram o povoamento nessa região, o município guarda um acervo de riqueza préhistórica, histórica e cultural de grande relevância para o Estado, com sítios arqueológicos, monumentos arquitetônicos, formações geológicas, casas de fazendas do período colonial, além das tradições e saberes existentes na história e na memória do seu povo. Esta diversidade foi reconhecida quando tombados pelo Instituto do Patrimônio Histórico Artístico Nacional (IPHAN), dois prédios, a Casa de Câmara e Cadeia, atual sede do Museu Histórico de Acari e a Capela de Nossa Senhora da Guia, hoje, Igreja de Nossa Senhora do Rosário, datada do século XVIII.

Porém, Acari não se restringe apenas aos atrativos histórico-culturais, o município tem grande potencialidade a ser explorada e desenvolvida no que diz respeito ao uso dos recursos naturais. Principalmente na região do Açude Marechal Dutra, conhecido popularmente como Açude Gargalheira, este construído entre os gargalos formados pelas serras, sendo um dos maiores reservatórios de água do interior do estado, está localizado a $4 \mathrm{~km}$ do centro da cidade. Além do próprio açude, existem inúmeros recursos naturais que podem ser explorados para fins turísticos como foi identificado no inventário realizado, como exemplo, as várias serras que circundam o reservatório e que oferecem inúmeras opções de trilhas, atividades de aventura, interpretação e contemplação da paisagem. 


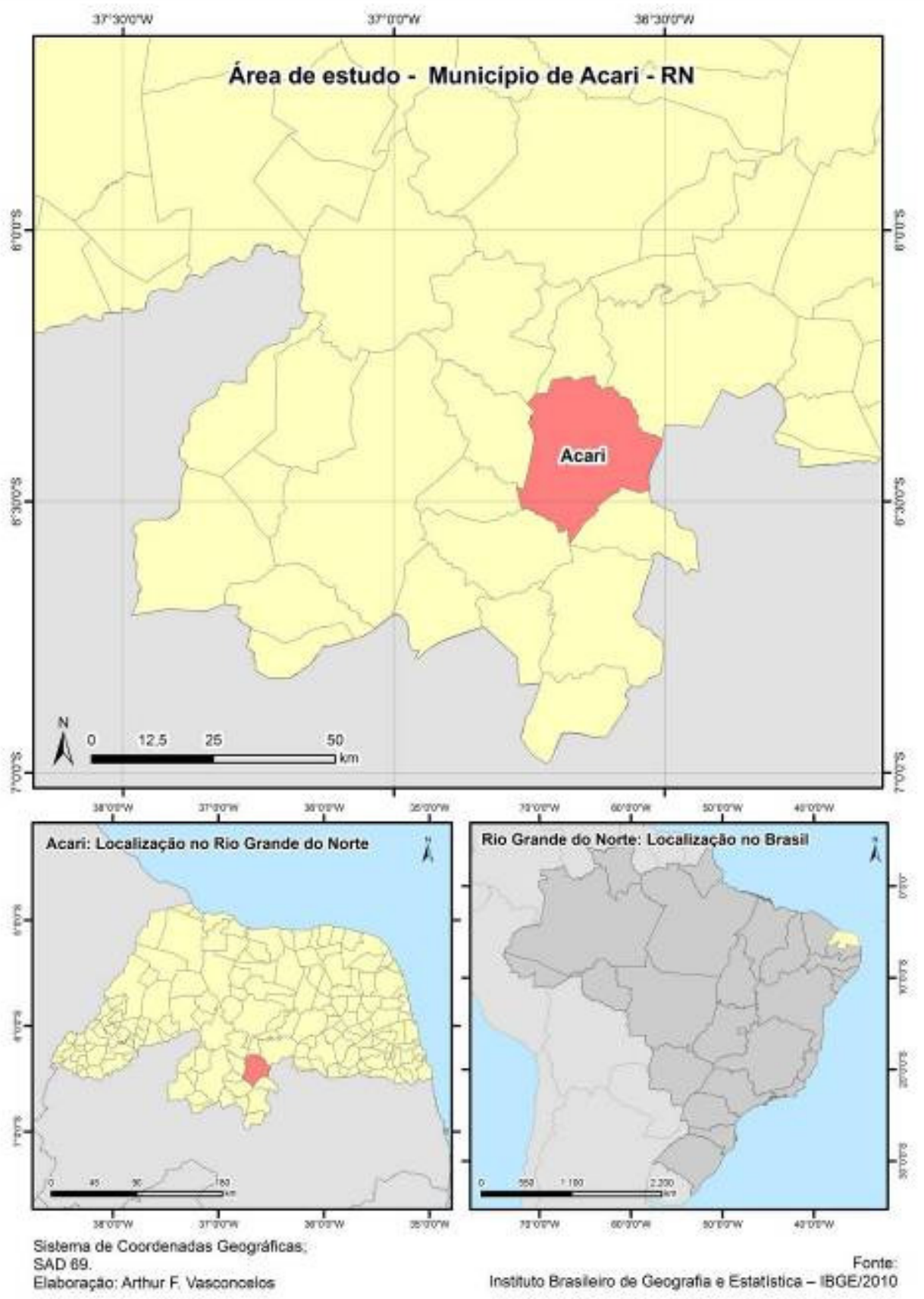

Figura 1: Localização do objeto de estudo. Fonte: Vasconcelos (2014). Figure 1: Location of the object of study. Source: Vasconcelos (2014).

\section{Perfil socioeconômico do público que visita Acari}

A identificação do perfil socioeconômico do público que visita um município é considerada uma informação importante, pois a partir delas podem ser elaboradas medidas e tomadas decisões mais precisas, bem como elaboradas políticas públicas municipais voltadas para 0 desenvolvimento ordenado do turismo local, buscando assim, a maximização e o uso racional dos recursos financeiros existentes. A pesquisa de campo teve início dia 8 de setembro de 2012 e seu término se deu no dia 27 de setembro de 2012, sendo aplicados 94 questionários. 
Antes de apresentar os resultados referentes ao perfil dos entrevistados, vale destacar a diferenciação entre as categorias de excursionistas e turistas. De acordo com a OMT (2001) os turistas são aqueles que permanecem pelo menos 24 horas no local visitado e cujos motivos da viagem estão agrupados em lazer (férias, prazer, religião, prática de esportes, tratamento de saúde e realização de estudos), negócios (interesses particulares, missões e reuniões) e razões familiares. Excursionista é o visitante temporário que permanece no local visitado menos de 24 horas. Já os excursionistas são aqueles que se deslocam para um local diferente da sua residência em até 24 horas, porém temporariamente sem pernoitar no local visitado. Apresentada as diferenças entre os tipos de visitantes denominados de turistas e excursionistas podese caracterizar com maior propriedade o perfil do público que visita o município de Acari-RN.

Com relação ao sexo do público predominaram os homens compreendendo $65,21 \%$ dos questionados, enquanto as mulheres corresponderam a $34,79 \%$. Já o grau de instrução do público, ou seja, sua escolaridade foi determinada assim, a maioria possui $2^{\circ}$ grau completo, contabilizando $65,57 \%$, enquanto os demais estão divididos entre superior incompleto e completo, pós-graduação e $1^{\circ}$ grau incompleto. Na faixa etária do público predomina em maior concentração adultos entre 21 e 40 anos de idade, ou seja, um público jovem que se trabalhado, pode voltar-se para o consumo de serviços e produtos do ecoturismo e do turismo de aventura. Esses dados já dão indício de que a maioria dos visitantes viaja a trabalho, tendo em vista que a maioria são homens que estão sozinhos, pois geralmente quando viajam a lazer trazem consigo parentes e amigos.

No que diz respeito ao meio de transporte utilizado para viagem, a maioria do público, 56,52\%, optaram por viajar de carro de passeio próprio, enquanto apenas cerca de $20 \%$ viajam de ônibus, sejam eles fretados ou de linha regular, isso ainda deixa transparecer a má qualidade do transporte público regional, fazendo com que os turistas optem por outros meios de transportes, mesmo sendo mais onerosos. Quanto à forma de viagem, foi questionado se viajavam sozinhos, com amigos ou familiares, ou ainda em excursão organizada. O resultado obtido foi o seguinte: $39,13 \%$ viajam sozinhos, $26,05 \%$ viajam entre amigos e $17,40 \%$ entre a família. Apenas $8,9 \%$ viajam em excursões organizadas por agências de viagem e 8,69\% em excursão organizadas por conhecidos, o que transparece mais uma vez que Acari ainda não é apontada como uma opção de destino turístico pela maioria das empresas do setor, mesmo existindo roteiros institucionais formatados de toda a região do Seridó em diferente segmentos, do qual o município faz parte.

Também, foi levantado o tempo de permanência do público no município de Acari, cerca de $40 \%$ afirmaram permanecer apenas um dia no local, seguido de $20 \%$ que passam apenas meio dia, um final de semana ou um mês quando no período de férias. Um aspecto identificado na pesquisa é que a maioria do público costuma pernoitar na cidade, o que acaba beneficiando a economia local com a entrada de mais recursos financeiros provenientes com estadas, alimentação e outros gastos. Ainda, grande porcentagem do público afirmou passar mais de uma semana na cidade, 
isso se configura estadas em casas de parentes ou amigos, visto o longo período, raramente permanecem hospedados em pousadas durante tanto tempo, a não ser por motivos vinculados a negócio. Então, podemos afirmar que dos $20 \%$ que permanecem apenas meio dia, um final de semana ou um mês no período de férias, cerca de $8 \%$ foram identificados como excursionistas, ou seja, não pernoitam no município. Já o grande montante, cerca de $92 \%$, pode ser caracterizado como turistas com foco em atividades de negócio.

No que diz respeito à frequência de visitas a cidade, pode-se afirmar que muitos turistas frequentemente viajam a Acari visto a porcentagem identificada na pesquisa, poucos apontaram que visitavam pela primeira vez a cidade, isso se deve principalmente por que a maioria viaja a trabalho e não por atividades de lazer. Ainda foi levantado o meio de hospedagem utilizado durante a estada na cidade, foram apontados principalmente o uso de pousadas e casas de parentes e amigos ambos totalizando cerca de $90 \%$ das escolhas. A respeito dos atrativos que motivaram a visita de turistas ao município, os visitantes elencaram (Figura 2):

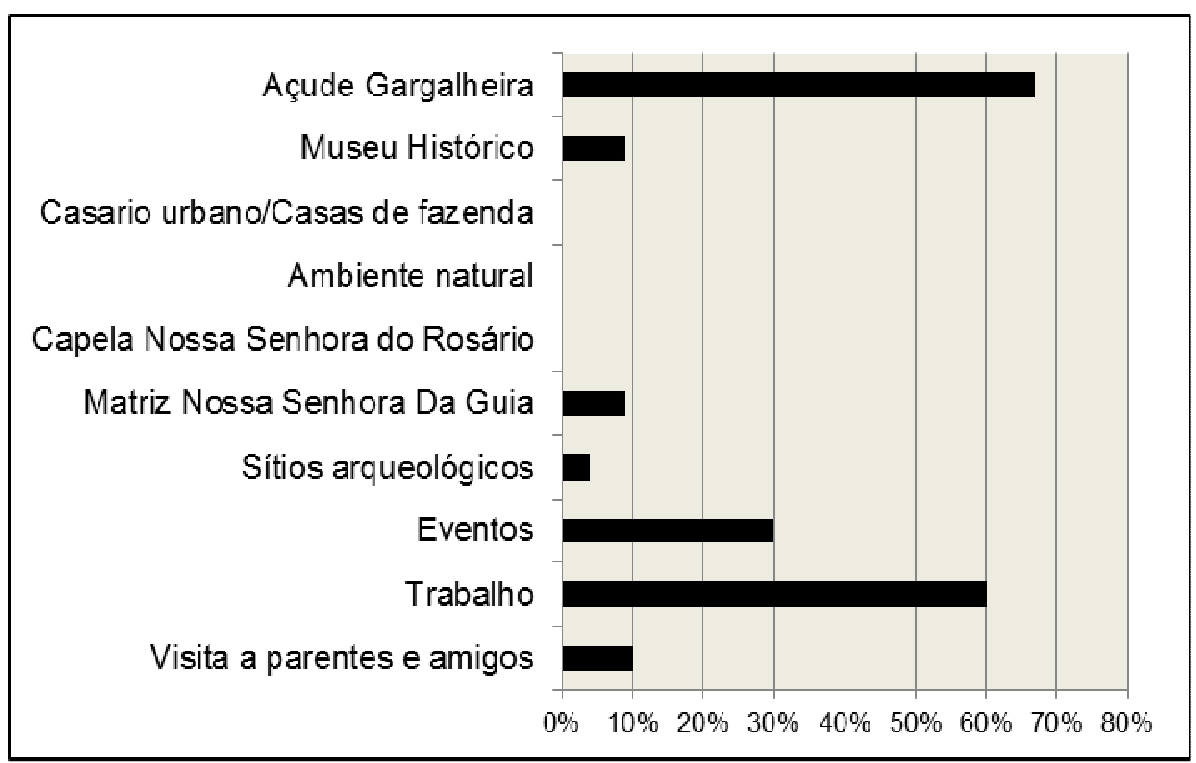

Figura 2: Atrativos que motivaram os turistas a visitarem Acari. Fonte: Dados da pesquisa.

Figure 2: Attractions that motivate tourists to visit Acari. Source: Research data.

Apesar de o Açude Gargalheira motivar a visitação de turistas em maior número, os negócios e os eventos existentes na cidade configuram-se como dois dos principais motivos das visitas e viagens. No que condiz a média diária de gastos em reais dos turistas, durante sua visita a Acari, $80 \%$ responderam que gastam até $R \$ 50,00$, enquanto apenas $20 \%$ afirmaram ultrapassar $\mathrm{R} \$ 100,00$ em gastos diários. Em virtude desse resultado percebe-se que boa parte dos gastos dos turistas realmente é com alimentação e hospedagem, deixando de consumir outros produtos locais, tais como, artesanato e souvenires, entretenimento, entre outros. Por outro lado, percebe-se que também há uma interação de turistas com a população local para além de uma relação comercial, como aponta 
Swarbrooke (2000), pois o ecoturismo estimula o desejo dos turistas em visitar ecossistemas preservados, e consequentemente pode melhorar as condições sócio econômicas da população local.

Por último, o formulário de pesquisa contemplava o local de origem dos turistas, em sua maioria, cerca de $56 \%$ dos turistas disse ser proveniente de cidades circunvizinhas, todas da região do Seridó como, Currais Novos, Carnaúba dos Dantas, Parelhas, Jardim do Seridó, Caicó e Cruzeta. Outros $34,78 \%$ foram provenientes de Natal e Região metropolitana, e em menor escala foram os turistas provenientes de outras regiões e estados como o da Paraíba, totalizando apenas $8,70 \%$.

Portanto, a pesquisa realizada mostrou que a maioria dos turistas que visita Acari, principalmente durante a semana, é de pessoas motivadas por negócios, elas costumam permanecer no município no máximo um dia, ou ainda pernoitam, tem gastos mínimos com alimentação e hospedagem, e são provenientes da região do Seridó, principalmente dos municípios de Caicó e Currais Novos.

Outra parcela de turistas em Acari são os que visitam a cidade nos finais de semana, geralmente permanecem no local um ou dois dias em casas de parentes e amigos, costumam usufruir de serviços de alimentação e entretenimento e visitam os atrativos turísticos do município, esses têm gastos mais elevados a partir de $R \$ 100,00$ (cem reais) por pessoa e frequentemente estão fazendo novas visitas, também são provenientes de cidades circunvizinhas, porém também há um fluxo significativo de turistas de outras regiões, principalmente de Natal e seu entorno.

O fluxo turístico proveniente de outras regiões do estado, além de estados vizinhos reforça a necessidade de um trabalho integrado no processo de planejamento de serviços e roteiros turísticos, conforme citado por diferentes teóricos como Bahl (2004) e Ruschmann (2001).

A identificação do perfil de visitantes e turistas é importante, pois, a partir da análise dessas informações, é possível elaborar políticas e estratégias para a organização dessa demanda, ou mesmo sua diversificação com 0 intuito de atrair segmentos diferentes de turistas. Desse modo, possíveis investimentos no setor podem gerar retornos financeiros mais positivos. Essa caracterização do perfil dos turistas, junto à inventariação da oferta turística local são fatores fundamentais ao desenvolvimento da atividade turística em qualquer região.

\section{Inventário e hierarquização dos atrativos naturais}

É muito difícil desenvolver as potencialidades turísticas de uma determinada localidade sem planejamento. Esse processo exige consistência e confiabilidade dos dados que servem como base para análises e tomada de decisões acertadas posteriormente. Portanto, esse tipo de informações deve ser gerada através do inventário, pois é capaz de fornecer elementos que subsidiam diagnósticos e prognósticos mais precisos. Esse método permite conhecer as características, a dimensão da oferta e, ainda, o que necessita passar por melhorias ou aperfeiçoamento, quais as iniciativas que devem ser tomadas e que podem permitir aos 
municípios, regiões, estados e ao país desenvolver o turismo mais competitivo e sustentável.

A atratividade de determinado local é subjetiva, o que para determinado grupo de pessoas é muito interessante, para outro pode ser indiferente. Porém, um atrativo que seja único, sem outros semelhantes, geralmente possui maior valor para os turistas. Em detrimento disso, teve-se como base a Metodologia de Hierarquização dos Atrativos Turísticos proposta pelo Ministério do Turismo adaptada a partir da sugestão da Organização Mundial do Turismo (OMT) e pelo Centro Interamericano de Capacitação Turística (CICATUR).

A aplicação dessa metodologia tem como objetivo principal avaliar o papel dos atrativos identificados para inclusão no roteiro turístico. Com este instrumento são estabelecidas prioridades para determinar a escolha e as decisões das entidades públicas e privadas, gestores e empreendedores. Em primeiro lugar, deve-se avaliar o potencial de atratividade do elemento conforme as características e peculiaridades e 0 interesse que pode despertar nos turistas como segue (Quadro 1).

Quadro 1: Critérios quantitativos para priorização de atrativos no desenvolvimento da atividade turística.

Table 1: Quantitative criteria used to prioritize attractions in the development of tourist activities).

\begin{tabular}{|c|c|}
\hline HIERARQUIAS & CARACTERÍSTICAS \\
\hline $\begin{array}{c}3 \\
\text { (alto) }\end{array}$ & $\begin{array}{c}\text { Todo atrativo turístico excepcional e de grande interesse, com significação para o } \\
\text { mercado turístico internacional, capaz de, por si só, motivar importantes correntes } \\
\text { de visitantes, atuais e potenciais. }\end{array}$ \\
\hline $\begin{array}{c}2 \\
\text { (médio) }\end{array}$ & $\begin{array}{l}\text { Atrativos com aspectos excepcionais em um país, capazes de motivar uma } \\
\text { corrente atual ou potencial de visitantes deste país ou estrangeiros, em conjunto } \\
\text { com outros atrativos próximos a este. }\end{array}$ \\
\hline $\begin{array}{c}1 \\
\text { (baixo) }\end{array}$ & $\begin{array}{c}\text { Atrativos com algum aspecto expressivo, capazes de interessar visitantes } \\
\text { oriundos de lugares no próprio país, que tenham chegado à área por outras } \\
\text { motivações turísticas, ou capazes de motivar fluxos turísticos regionais e locais } \\
\text { (atuais e potenciais). }\end{array}$ \\
\hline $\begin{array}{c}0 \\
\text { (nenhum) }\end{array}$ & $\begin{array}{l}\text { Atrativos sem méritos suficientes, mas que são parte do patrimônio turístico como } \\
\text { elementos que podem complementar outros de maior hierarquia. Podem motivar } \\
\text { correntes turísticas locais, em particular a demanda de recreação popular. }\end{array}$ \\
\hline
\end{tabular}

Fonte: MTUR (2005).

Source: MTUR (2005).

Posteriormente, foram avaliados os aspectos que definem a hierarquia. Esse critério permite classificar cada atrativo de acordo com uma escala preestabelecida. Assim, pode fornecer subsídios para a diferenciação objetiva das características e do nível de importância de cada atrativo (Quadro 2).

1. Grau de uso atual: permite a análise do fluxo turístico efetivo e sua importância para a localidade. Difere do grau de interesse por representar a situação atual, em vez da potencial. 
2. Representatividade: fundamenta-se na singularidade, peculiaridade ou raridade do atrativo. Quanto mais semelhante for a outros atrativos, menos interessante ou prioritário.

3. Apoio local e comunitário: análise do grau de interesse da comunidade local para o desenvolvimento e disponibilidade ao público.

4. Estado de conservação da paisagem circundante: verificação, por observação in loco, do estado de conservação da paisagem que rodeia 0 atrativo.

5. Infraestrutura: verificação, in loco, da infraestrutura disponível no atrativo e o seu estado de conservação.

6. Acesso: verificação das vias de acesso existentes e suas condições de uso.

Quadro 2: Critérios para hierarquização dos atrativos turísticos.

Table 2: Assessment methods for tourist attractions.

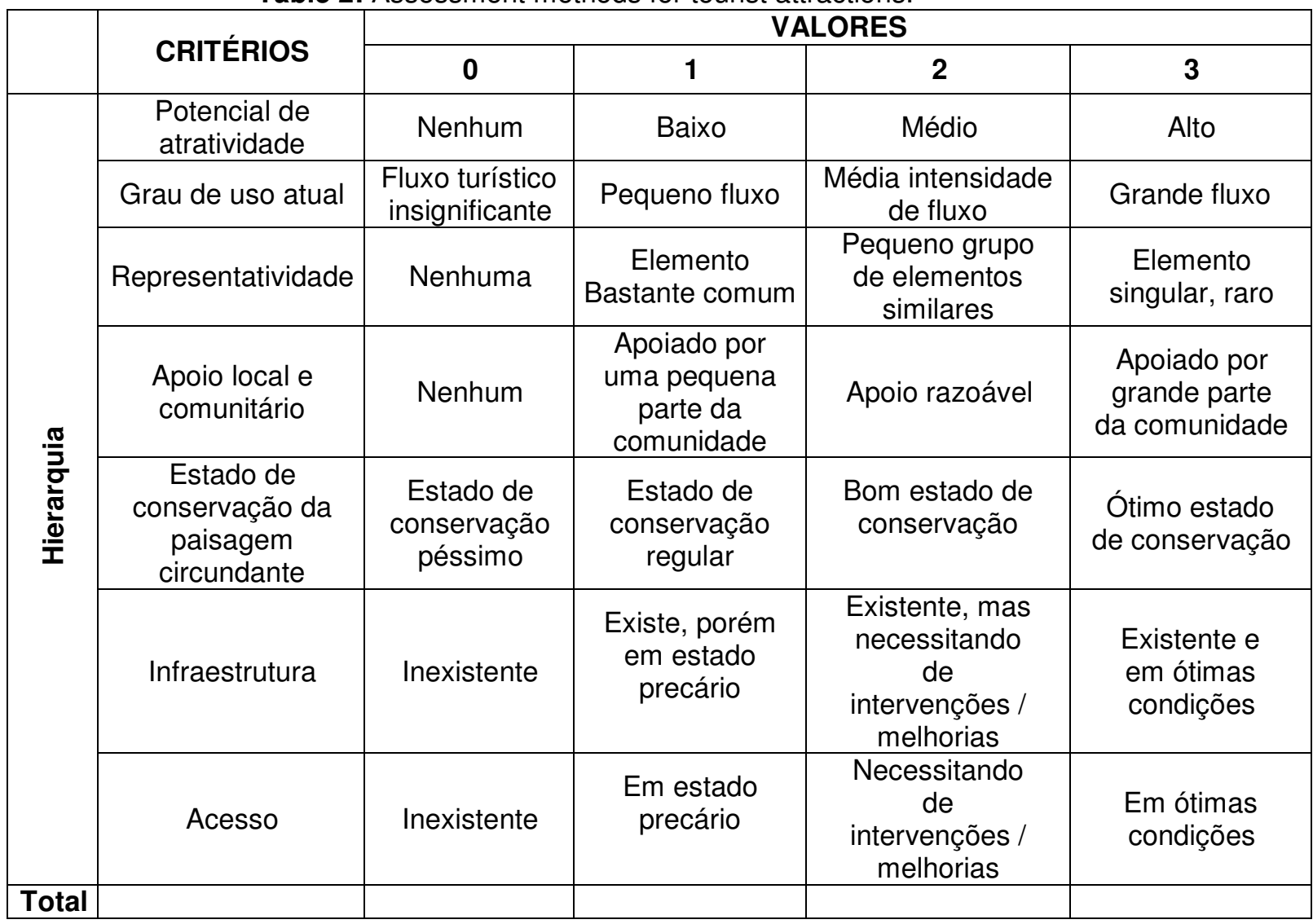

Fonte: MTUR (2005).

Source: MTUR (2005).

De acordo com as especificidades apresentadas no quadro, deve ser preenchida a tabela de avaliação e hierarquização dos atrativos, onde são atribuídos valores para cada item dos atrativos avaliados. É importante ressaltar que os itens "potencial de atratividade do elemento" e "representatividade" devem receber a pontuação em dobro por serem mais significativos em comparação com os demais itens avaliados. Por último, são somados os pontos obtidos e define-se o ranking de atrativos. Quanto 
maior o número de pontos de determinado atrativo, maior sua importância e necessidade de ser incluído nos roteiros elaborados. O ranking dos principais atrativos possibilitou a inclusões destes na composição dos roteiros, como será apresentada mais a seguir.

Essa classificação é fundamental na composição de roteiros turísticos, pois ajuda a focalizar investimentos e na proposição de infraestruturas envoltas aos atrativos que realmente são capazes de atrair fluxos consideráveis de turistas. Para tanto, uma nova perspectiva de desenvolvimento apontada pelo governo federal se dá através da formatação de roteiros turísticos, estes criados a partir do ponto de vista do planejamento turístico regional, em virtude disso, foi lançado o programa Roteiros do Brasil que propõe o desenvolvimento da atividade turística de forma regionalizada, com foco no planejamento coordenado e participativo. Essa perspectiva torna-se uma alternativa viável para o crescimento da atividade, principalmente nas pequenas localidades, além disso, pode, não só contribuir para uma maior organização da oferta turística, bem como na sua diversificação.

Portanto, de posse dos formulários de inventariação propostos pelo MTUR (2011), na parte que trata dos atrativos naturais, foi possível identificar e caracterizar potenciais atrativos turísticos a serem contemplados nos roteiros. Realizada a triagem dos atrativos, pode-se realizar a hierarquização de cada um deles, estabelecendo seu valor intrínseco a partir da determinação de sua singularidade, facilidade de acesso, nível de visitação atual e presença de infraestrutura turística, entre outros. Para que isso fosse possível, baseou-se na metodologia de hierarquização dos atrativos turísticos proposta pelo MTUR, a fim de avaliar o nível de relevância de cada atrativo para formatação do roteiro turístico.

A hierarquização foi estabelecida da seguinte forma, cada local inventariado foi analisado separadamente, ou seja, cada Serra que comporá o roteiro teve seus atrativos avaliados individualmente, estabelecendo assim sua hierarquia, a partir de então foram formatados os roteiros, mesclando atrativos de maior representatividade e potencial com atrativos secundários, equilibrando dessa forma a oferta turística.

O primeiro local inventariado que teve seus atrativos hierarquizados foi a Serra do Cruzeiro, nela há atrativos turísticos de grande representatividade, que vão desde pequenos grupos de elementos similares, como é o caso do Mirante Natural do Cruzeiro de onde se pode contemplar toda a barragem do Gargalheira (Figura 3), até elementos singulares, esses raramente encontrados como a Pedra do Tubarão, cujo formato remete a um grande tubarão. Porém, percebeu-se também a necessidade de implantação de infraestrutura e de melhorias nos acessos, principalmente no decorrer das trilhas. Para que possa ser ofertada com comodidade, seria necessária a criação de simples degraus e em alguns trechos da trilha, a instalação de escadas com corrimãos, em virtude da necessidade de maior segurança já que se trata de um local de difícil acesso. Além disso, a disposição de uma estrutura de mirante no alto da Serra proporcionaria maior visualização do entorno e segurança da integridade física dos turistas, gerando uma maior satisfação com a visita. 


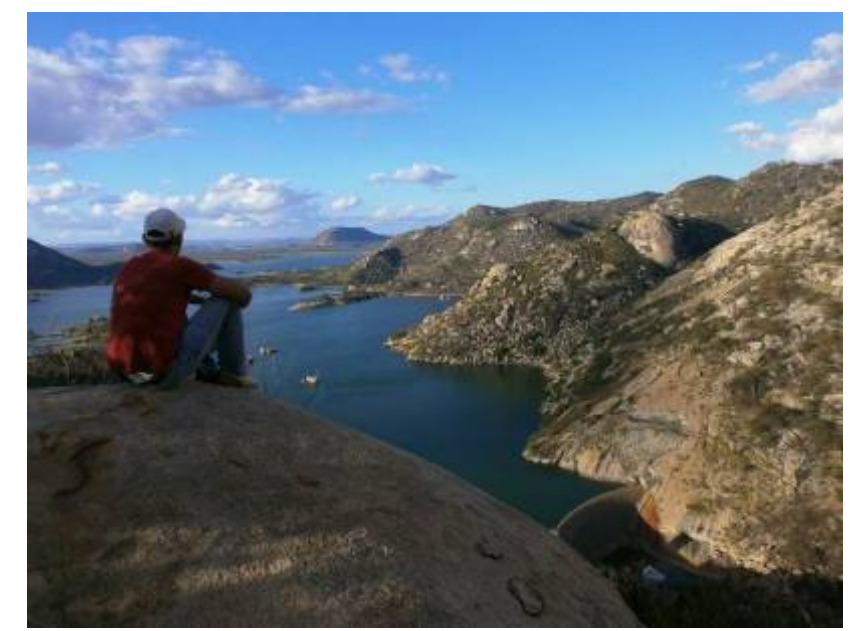

Figura 3: Vista do Mirante do Ninho do Gavião. Fonte: Russo (2012).

Figure 3: View of Ninho do Gavião (Hawk's nest). Source: Russo (2012).

Ainda, devido à proximidade com a Vila de Pescadores, é importante que haja a interação com a comunidade local, o turista pode presenciar 0 cotidiano dos pescadores e todos os processos diários de sua atividade, como a limpeza do camarão e preparação do filé de peixe, bem como a produção de artesanato. Um espaço adequado para que isso ocorra, além das próprias residências dos habitantes, tendo em vista que muitos dessas atividades ocorrem nos alpendres das casas, é o Terminal Turístico Oscar Alberto Dantas localizado no Complexo Gargalheira, que fica ocioso durante quase todo o ano, exceto no período que compreende as comemorações do Festival do Pescado. Ali poderiam ser estruturados estandes não só para comercializar a produção de artesanato, como também para a criação de um pequeno museu retratando a história da construção do açude e demais aspectos.

A comunidade local entende que o desenvolvimento do turismo poderia proporcionar vários aspectos positivos, principalmente de caráter econômico. Isso em virtude das receitas geradas pelos turistas nos períodos de eventos no Complexo Gargalheira (Festival do Pescado, Moto Fest e Torneio Leiteiro). Assim, entende que um fluxo contínuo de turistas, proporcionado pela diversificação da oferta, poderia incrementar a economia local através das vendas dos produtos derivados do pescado (camarão, filé de peixe, linguiça de camarão, além das comidas típicas), do artesanato e da prestação de serviços (guiamento, passeio de canoa, aluguel de imóveis, entre outros). Porém, enxerga as dificuldades encontradas para que isso ocorra, entre elas: a falta de um planejamento adequado, infraestruturas precárias ou inexistentes, desinteresse público e privado, além de reconhecer que a maioria deles não está preparada para receber o fluxo de visitantes, pois falta capacitação profissional.

Já na Serra do Abreu foram identificados os atrativos com maior representatividade e potencial de atratividade como é o caso do Poço do Letreiro onde podem ser encontradas pinturas rupestres e o Poço Fundo, no qual os turistas após a longa caminhada, podem se banhar em sua água limpa e fria e usufruir da qualidade paisagística do entorno. Além disso, existem também atrativos de características complementares como o Olho 
D'água do qual se obtém água limpa e potável, e a Passagem do Apertadinho. Outra característica interessante da Serra do Abreu é que ela se mantém num bom grau de conservação, poucas foram às mudanças negativas ocorridas em virtude da ação humana. Ainda, em virtude da proximidade e de um dos acessos à Serra do Abreu ser por meio da travessia do açude, o Gargalheira (Figura 4) foi incluído como um dos atrativos desse local. De todos os atrativos turísticos, é o que mais motiva e recebe o fluxo turístico no município, por isso sua "representatividade" é a mais alta.

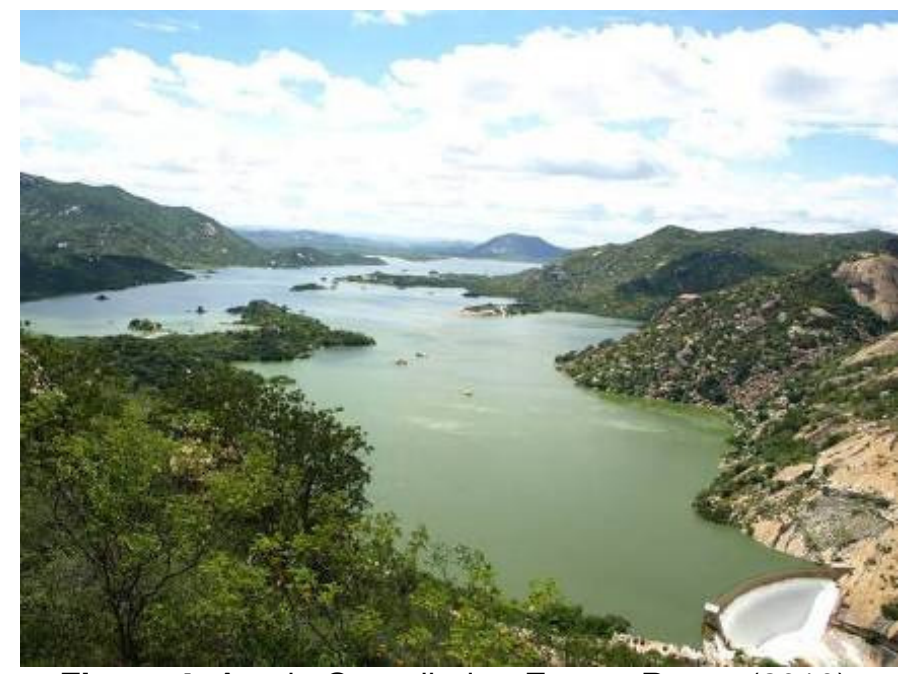

Figura 4: Açude Gargalheira. Fonte: Russo (2010).

Figure 4: Gargalheira Dam. Souuce: Russo (2010).

Porém, como na Serra do Cruzeiro, também se faz necessária a criação de estruturas e melhorias nos acessos. Por ser a visita nesse local mais cansativa, em virtude do grande percurso realizado a pé, cerca de 5 $\mathrm{km}$, seria conveniente a instalação de assentos de madeira em pontos estratégicos onde os turistas poderiam contemplar a paisagem ao mesmo tempo em que descansam. Além disso, faz-se necessária a manutenção periódica dos pinos de sustentação utilizados para a prática do rapel, tendo em vista que ficam expostos a ação do vento, do sol e da chuva.

Outra localidade inventariada foi a Serra do Minador, essa serra foi incorporada no roteiro porque é privilegiada geograficamente. No decorrer das trilhas, o turista é capaz de contemplar boa parte da paisagem circundante do Gargalheira e, chegando ao alto, no Mirante do Minador, é presenteado com uma das mais belas paisagens da região. Outro aspecto importante a destacar é o excelente estado de conservação ambiental, poucas são as alterações na natureza promovidas pelo ser humano no local. Além da paisagem a ser contemplada e interpretada pelos turistas no alto da Serra, também há um paredão rochoso propício para a prática de rapel com cerca de 30 metros de altura, uma excelente opção aos visitantes com espírito de aventura.

Já na Serra do Pai Pedro há uma particularidade interessante, um local propício à realização de acampamentos, com uma vista privilegiada de toda região de entorno e com ambiente agradável. Além disso, há uma grande quantidade de andorinhas (Melopsittacus undulatus) que vivem no 
local, ao fim da tarde elas propiciam uma experiência singular com voos rasantes até pousarem na furna em que dormem. Outro atrativo interessante é o Poti, um grande buraco na rocha na qual não se consegue enxergar o fundo, neste local os visitantes podem se banhar, porém apenas no período das chuvas. Há também, um paredão rochoso com cerca de 80 metros de altura, nele podem ser desenvolvidas atividades de escalada e rapel. Entretanto, o percurso até chegar ao local é mais longo que as demais Serras que compõem o roteiro, o que exige maior preparo físico dos visitantes.

Na Serra da Lagoa Seca é onde se localizam as torres de rádio, TV e telefonia móvel, por isso há um acesso pavimentado até o alto da serra. Há, porém, uma trilha que inicia no Povoado Gargalheira e que leva até seu cume, essa trilha pode ser feita a pé ou, preferencialmente, de bicicleta, em virtude de seu tamanho, cerca de $8 \mathrm{~km}$. Destacam-se os mirantes naturais, cada um propicia uma visualização diferente do Açude Gargalheira, pois estão em ângulos opostos, um no lado norte e outro no lado sul da serra. Assim, após inventariação e hierarquização dos atrativos naturais, foi estabelecida a pontuação de cada um deles e a partir daí puderam ser formatados os roteiros ecoturísticos aqui propostos.

\section{Proposta de roteiros ecoturísticos para o município de Acari (RN)}

A roteirização turística é uma ação importante que pode estimular o desenvolvimento do turismo, pois é capaz de auxiliar na integração e organização dos atrativos, equipamentos, serviços turísticos e infraestrutura de apoio ao turismo, resultando na maior consolidação dos produtos do local, além de conferir maior uso turístico aos atrativos que estão dispersos. Ainda, a formatação de roteiros pode adequar 0 ordenamento e disseminação da demanda turística em todas as localidades da região.

Os roteiros aqui propostos possibilitarão uma nova perspectiva para o desenvolvimento do ecoturismo no município de Acari, organizando a oferta turística local, tendo em vista que estimulam a identificação e o poder de atratividade do destino, tornando-o mais rentável e comercialmente viável. Quando implantados da maneira correta podem contribuir tanto para o aumento do fluxo de turistas no destino, como para aumentar seu tempo de permanência e os gastos que realizam durante a viagem.

Os roteiros aqui propostos possuem um caráter operacional, tendo em vista que após definido o destino, produtos e o próprio roteiro, 0 responsável pela formatação do produto, ou seja, o operador local deve formalizar e organizar as informações a respeito do produto para que assim possa ofertá-lo de acordo com as necessidades de mercado e de operação. Sua principal função é o planejamento do roteiro e direcionamento da equipe de operação, ou seja, guias, condutores e demais serviços incluídos, com intuito de padronizar as atividades e garantir a execução da operação com maior qualidade e segurança. Diferente do roteiro descritivo que possui um caráter comercial e como o próprio nome aponta, descreve todas as atividades nele contidas de maneira atrativa, utilizando a linguagem 
comercial direcionada à venda do produto, seja para clientes ou agentes de viagens (CREATO, 2005).

\section{Roteiro I: a Verdadeira Caatinga}

O "Roteiro I" foi elaborado visando aproveitar ao máximo a disposição física inicial dos visitantes, tendo em vista que carecem de maior esforço físico em virtude dos deslocamentos realizados, tanto para chegar ao local como às próprias ecotrilhas. Recebe este nome porque a maioria dos visitantes possui uma visão distorcida da região, acham que é tudo muito seco e sem vida, no decorrer das trilhas terão a oportunidade de conhecer a verdadeira beleza e as características presentes nesse bioma único, podendo assim desvencilhar-se dessa imagem preconcebida do local. Ainda, faz-se necessária a travessia, por meio de embarcações, do Açude Gargalheira para que se possa ter o acesso até o local de início da trilha. $O$ "roteiro I" é formado pelos seguintes produtos como segue adiante:

\section{Produto I: Acampamento do Poti}

\section{Local: Serra do Pai Pedro}

Depois de realizada a travessia do Açude, o que já se caracteriza como uma atração turística, os visitantes se acomodam na Pousada Pé de Serra. No período da tarde é realizada a primeira trilha (cerca de 3,5 km) até - local do acampamento, após a chegada a Serra do Pai Pedro são montadas as barracas e posteriormente os visitantes são encaminhados a Furna das Andorinhas onde elas dormem para que possam contemplar o seu voo. No dia seguinte pela manhã, é realizado o Rapel 01 com cerca de 80 metros de altura (opcional) ou ainda a escalada no mesmo local, os turistas que não desejarem executar as atividades de aventura, poderão fazer a interpretação ambiental da localidade, visto a grande diversidade de plantas, animais silvestres e formações geológicas, após o término das atividades os turistas são encaminhados de volta à pousada.

\section{Produto II: Ecotrilha do Abreu}

\section{Local: Serra do Abreu}

De volta à Pousada Pé de Serra, os turistas podem descansar e alimentar-se, tendo toda a tarde para desenvolver as atividades nas águas do Açude Gargalheira, como passeios de barcos, prática de natação, interpretação ambiental, entre outras. No dia seguinte pela manhã, é realizada a Ecotrilha do Abreu (cerca de $6 \mathrm{~km}$ ) onde é contemplada a bela paisagem da região de um dos pontos mais altos do município no Mirante das Torres e no Mirante do Olho do Pirú. Desses locais podem ser contemplados a Pedra da Santa, formação rochosa semelhante à imagem de uma santa. Posteriormente, os turistas podem descansar na parada estratégica realizada na residência de Seu Zé Felipe e Dona Maria, únicos moradores do local, ainda refrescar-se com a água límpida do Olho D’água. Dando continuidade a trilha, tem-se acesso ao Poço do Letreiro, onde estão 
localizadas várias pinturas rupestres e logo ao lado o Poço Fundo onde os turistas podem banhar-se, a água desse local é muito fria em virtude de sua profundidade. Próximo ao Poço Fundo está localizado o Poço do Arroz, onde há inúmeras pinturas e incisões rupestres. Terminada a trilha, trajeto realizado em média em $4 \mathrm{~h}: 30 \mathrm{mim}$, os turistas são direcionados à Pousada Gargalheiras.

\section{Roteiro II: Açude Do Gargalheira}

O "roteiro II" compreende trilhas de duração mais curta, por isso é realizado por último, tendo em vista que os turistas já tenham se esforçado intensamente nos dois primeiros dias do passeio. Recebe esse nome porque é do alto das serras que compõem esse roteiro que é possível observar toda a imensidão do Açude Gargalheira. Foi nesse trecho que se identificou as maiores necessidades de melhorias nos acessos das trilhas e criação de estruturas de apoio em virtude do relevo dos locais. O "roteiro II" é formado pelos seguintes produtos como segue adiante:

\section{Produto I: Ecotrilha do Minador}

\section{Local: Serra do Minador}

A ecotrilha tem início nas proximidades da Vila de Pescadores no Povoado Gargalheiras, esse percurso de $2,5 \mathrm{~km}$ tem vários pontos de observação, um deles é o Mirante da Caverninha, uma formação rochosa em que o turista fica dentro de uma espécie de salão encravado na rocha podendo visualizar toda a região. Seguindo pela trilha, chega-se ao Mirante do Minador no alto da serra, um local único de onde se pode observar toda a região num ângulo de $240^{\circ}$, no local também é possível realizar um rapel com cerca de 30 metros de altura.

\section{Produto Il: Ecotrilha Via Crucis.}

\section{Local: Serra do Cruzeiro}

A trilha da Serra do Cruzeiro apesar de ser um local, em determinado trecho, de difícil acesso, é bem rápida, em virtude de o percurso ser curto, cerca de 800 metros. Nela pode ser visualizada uma das mais belas paisagens da região do alto do Mirante do Ninho do Gavião, além disso, o turista pode contemplar interessantes formações rochosas como a Pedra do Tubarão e a Pedra do Divã.

\section{Produto III: Ecotrilha das Torres (Bicicleta).}

\section{Local: Serra da Lagoa Seca}

Nessa serra estão localizadas as torres de telefonia móvel, TV e rádio, por isso a trilha recebe esse nome. É um local propício a prática do ciclismo, pois já há uma trilha aberta pelo homem que dá acesso até o alto da serra. Porém a chegada à serra deve ser realizada pelo acesso pavimentado, construído quando foram instaladas as torres no local, tendo 
em vista que alguns trechos da trilha são acentuados e necessitaria de um grande esforço físico dos turistas. Os visitantes seriam deslocados através de carros e, chegando ao alto da serra contemplariam o Açude Gargalheira de um ângulo diferente do normalmente visto e divulgado pela mídia, um do Mirante do Tanque e outro do Mirante do Poste. Após interpretação e contemplação do ambiente, seria iniciada a trilha com bicicletas por um caminho diferente do inicial (cerca de $8 \mathrm{~km}$ ), que dá acesso direto ao Complexo Gargalheira, no percurso de volta não há trechos acentuados, propiciando maior conforto aos turistas e a contemplação da paisagem do local.

Na Figura 5 segue uma imagem demonstrando, a partir de uma perspectiva panorâmica, o Layout das trilhas que compuseram os roteiros e as respectivas localidades. As trilhas foram demarcadas em diferentes cores para melhor compreensão, além de proporcionar uma ideia do tamanho do percurso a ser realizado pelos visitantes.

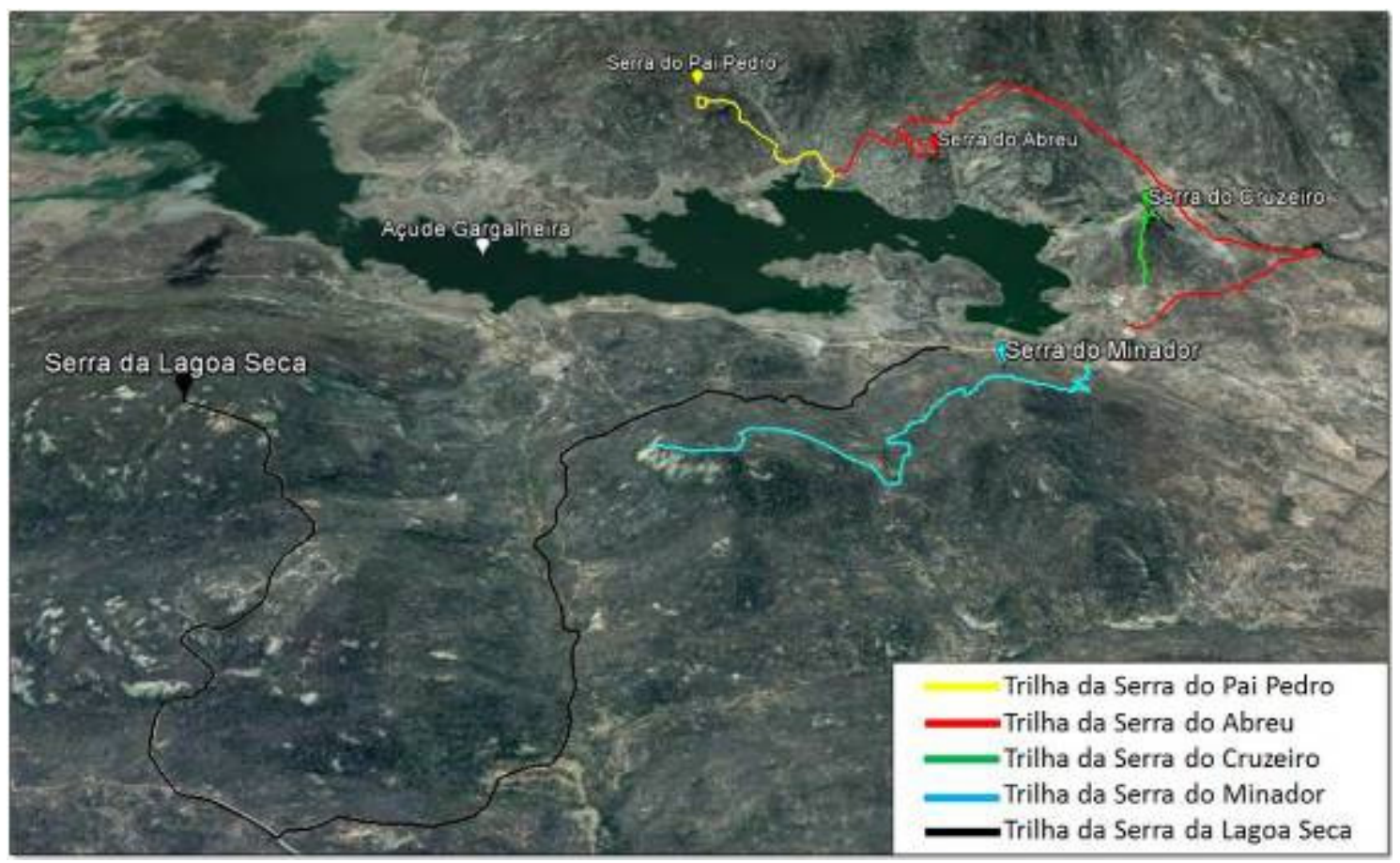

Figura 5: Imagem geral de todas as trilhas que compõe os roteiros. Fonte: Dados da pesquisa. Adaptado do Google Earth (2012).

Figure 5: Overview of trails within the tourist circuits. Source: Research data. Adapted from Google Earth (2012).

A integração desses atrativos pode proporcionar a atração de um fluxo turístico significativo e de um tipo de turista que tem aumentado em todo o mundo, o ecoturista. Além disso, mostra-se uma alternativa para a diversificação da oferta turística local que hoje está baseada principalmente no turismo de eventos, esses que são bem pontuais e não geram o efeito multiplicador esperado. Outra modalidade turística do município é o turismo religioso que acontece de forma esporádica em virtude da comemoração anual da festa da padroeira local. 


\section{Considerações finais}

O ecoturismo tem se mostrado como uma alternativa viável para o incremento do setor turístico em diferentes lugares do planeta, principalmente na busca pela diversificação da oferta turística local e por uma atividade sustentável que se desenvolva sem comprometer a qualidade de vida das populações locais e dos recursos naturais existentes. Além dele, outro segmento que tem apresentado um crescente desenvolvimento é o turismo de aventura, muito em decorrência da busca por hábitos saudáveis por parte das pessoas e também por estar atrelado muitas vezes ao ecoturismo. Nesse sentido foram propostos a formatação de roteiros que contemplassem as características de ambos os segmentos, a interação com o meio ambiente (natural, social e cultural), o respeito mútuo à natureza, à sustentabilidade da atividade e à prática de esportes de aventura com riscos controlados.

Assim, a formatação de roteiros ecoturísticos e de turismo de aventura, a partir de uma perspectiva de uso sustentável dos recursos naturais e culturais pode ser capaz de ordenar os elementos intervenientes na efetivação da viagem, estabelecendo diretrizes para desencadear o fluxo turístico e possibilitar o aproveitamento racional dos atrativos a visitar, proporcionando uma alternativa ao desenvolvimento local em diferentes regiões brasileiras. A exploração de segmentos alternativos ao turismo de massa configura-se como o "novo turismo", assim, os roteiros aqui propostos podem incrementar o desenvolvimento socioeconômico do município e, consequentemente, ser uma alternativa ao turismo de eventos amplamente explorado na região do Seridó Potiguar, além de possibilitar a redução da sazonalidade. Portanto, é preciso que haja um interesse maior do poder público municipal em efetivar as diretrizes contidas nos planos e programas criados pelo MTUR, pois são documentos e ações que podem nortear o desenvolvimento da atividade turística.

A pesquisa que permitiu exercitar um processo de construção prática numa lógica prevista e sugerida pelo MTUR, etapas estas que compõem o processo de planejamento e gestão do Programa de Regionalização do Turismo (PRT) voltado ao desenvolvimento turístico na Região do Seridó Potiguar, sobretudo ao município de Acari mostrou que é extremamente complexo o processo de formatação de roteiros turísticos, pois a atividade turística envolve diversos setores produtivos nos mais diversos níveis de interesse e desenvolvimento.

A atividade turística ainda ocupa a agenda de propostas de desenvolvimento conduzido pelo poder público, além de ser um dos setores mais defendidos por instituições não governamentais e privadas, como importantes para a melhoria da qualidade de vida da sociedade em geral. No entanto, as regras do jogo político, os arranjos institucionais que poderiam sustentar a cooperação e a coordenação das políticas, que atuam em prol do desenvolvimento turístico em Acari têm um nível qualitativo baixo, ou seja, atualmente não há ações efetivas por parte do poder público, em curto, médio e longo prazo que vislumbrem a possibilidade de desenvolvimento dos segmentos de turismo de aventura e ecoturístico que permitam um estímulo no investimento principalmente por parte dos empresários do setor. 


\section{Referências bibliográficas}

BAHL, M. Viagens e roteiros turísticos. Curitiba: Protexto, 2004.

BRAGA, D.C. Planejamento Turístico: teoria e prática. Rio de Janeiro: Elsevier, 2007.

BRASIL. Ministério do Turismo. Dados do turismo brasileiro. Brasília: Mtur, 2010a.

BRASIL. Ministério do Turismo. Programa de Regionalização do Turismo. Roteiros do Brasil: Diretrizes Políticas. Brasília: Mtur, 2004.

BRASIL. Ministério do Turismo. Inventário da oferta turística. Brasília: Mtur, 2011.

BRASIL. Introdução à regionalização do turismo. Brasília: Mtur, 2007.

BRASIL. Ministério do Turismo. Programa de Regionalização do Turismo Roteiros do Brasil: Módulo Operacional 7 - Roteirização Turística. Brasília, 2005.

BRASIL. Ministério do Turismo. Turismo de aventura: orientações básicas. Brasília, 2008.

BRASIL. Ministério da Indústria, do Comércio e do Turismo. Diretrizes para uma Política Nacional de Ecoturismo. Brasília/DF, 1994.

CEBALLOS-LASCURÁIN, H. O ecoturismo como um fundamento mundial. In: KREG, L.; HAWKINS, D. (Ed.). Ecoturismo: um guia para planejamento e gestão. 3. ed. São. Paulo: Senac, 2001. 3 ed. São Paulo: Senac, 2001.

CREATO. Manual técnico de desenvolvimento e operação de produtos e roteiros turísticos. CREATO oficina de roteiros, 2005.

FIGUEIREDO, L. G. B.B.; CAMPOS, J. G. C. Turismo de Esportes e Aventura: livro didático. Palhoça: SC, 2007. Disponível em: http://busca.unisul.br/pdf/88780 Luiz.pdf . Acesso em: 15 set. 2012.

GIL, A. C. Métodos e técnicas de pesquisa social. São Paulo: Atlas, 1999.

GOOGLE EARTH. Imagens de satélite. 2012. Disponível em: www.earth.google.com . Acesso em: 28 out. 2012.

HALL, C.M. Planejamento turístico: políticas, processos e relacionamentos. São Paulo: Contexto, 2004.

IBGE. Instituto Brasileiro de Geografia e Estatística. Censo 2010. Disponível em: http://www.ibge.gov.br/cidadesat/topwindow.htm?1. Acesso em: 25 out. 2012.

LOHMANN, G.; PANOSSO NETTO, A. Teoria do turismo: conceitos, modelos e sistemas. São Paulo: Aleph, 2008.

NÓBREGA, W. Turismo: planejamento e políticas públicas na Amazônia. Rio de Janeiro: E-papers, 2007. 
NÓBREGA, W.R.M. Turismo e políticas públicas na Amazônia brasileira: instâncias de governança e desenvolvimento nos municípios de Santarém e Belterra, oeste do estado do Pará. Belém: UFPA/PPGDSTU/NAEA, 2012. (Tese de doutorado).

OMT. Organização Mundial do Turismo. Dados do ecoturismo mundial. 2011. Disponível em: http://www2.unwto.org/. Acesso em: 25 set. 2012.

OMT. Organização Mundial do Turismo. Introdução ao turismo. São Paulo: Roca, 2001.

PIRES, P.S. Dimensões do ecoturismo. São Paulo: Senac, 2002.

RUSCHMANN, D. V. M. Turismo e planejamento sustentável: a proteção do meio ambiente. Campinas, SP: Papirus, 2001.

RUSSO, I. Acervo pessoal. 2010.

RUSSO, I. Acervo pessoal. 2012.

SWARBROOKE, J. Turismo sustentável: turismo cultural, ecoturismo e ética. São Paulo: Aleph, 2000.

Wilker Ricardo de Mendonça Nóbrega: Universidade Federal do Rio Grande do Norte, Natal, RN, Brasil.

E-mail: wilkernobrega@yahoo.com.br

Link para o currículo Lattes: http://lattes.cnpq.br/0025142529544906

Ítalo Victor de Souza Dantas: Universidade Federal do Rio Grande do Norte, Currais Novos, RN, Brasil.

E-mail: italo_vambeck@hotmail.com

Link para o currículo Lattes: http://lattes.cnpq.br/5436703875479648

Data de submissão: 21 de março de 2014

Data de recebimento de correções: 26 de julho de 2014

Data do aceite: 26 de julho de 2014

Avaliado anonimamente 